\title{
Elaboration and Characterization of Mullite Refractory Products from Moroccan Andalusite
}

\author{
Mostafa Sardy ${ }^{1}$, Abdelhak Arib ${ }^{1}$, Kacem El Abbassi ${ }^{2}$, Redouane Moussa ${ }^{1}$, Moussa Gomina ${ }^{3 *}$ \\ ${ }^{1}$ EMPM-LPCMI, Faculty of Science of Aïn Chock, Casablanca, Morocco; ${ }^{2}$ Centre for Study and Research of Mineral Phosphates, \\ Casablanca, Morocco; ${ }^{3}$ CRISMAT, UMR 6508 ENSICAEN/CNRS, Caen, France. \\ Email: ${ }^{*}$ moussa.gomina@ensicaen.fr
}

Received March $13^{\text {th }}, 2012$; revised May 25 ${ }^{\text {th }}$, 2012; accepted June $12^{\text {th }}, 2012$

\begin{abstract}
Enrichment of schist mined in Morocco resulted in an extract essentially made of andalusite, quartz and muscovite, which was investigated with the aim to synthesize mullite refractory materials. X-ray diffraction analysis was used to assess phase transformations upon heating at different temperatures. Mullite formation starts as early as $1200^{\circ} \mathrm{C}$ and seems almost total at $1450^{\circ} \mathrm{C}$. This process correlates with a weak shrinkage $\left(3.5 \%\right.$ at $\left.1450^{\circ} \mathrm{C}\right)$ and the formation of an important glass phase. Green compacts obtained by unidirectional pressing the extract powder were heated under air in the temperature range $1200^{\circ} \mathrm{C}-1600^{\circ} \mathrm{C}$. Chemical and mechanical properties of these materials were investigated and correlated with their microstructure.
\end{abstract}

Keywords: Andalusite; Mullite Refractory; Structure; Mechanical Properties

\section{Introduction}

Mullite is the only stable compound in the $\mathrm{SiO}_{2}-\mathrm{Al}_{2} \mathrm{O}_{3}$ diagram. It can be described by the formula $\mathrm{Al}_{4+2 x} \mathrm{Si}_{2-2 x} \mathrm{O}_{10-x}$ [1]. Its composition ranges from $x=0.25\left(3 \mathrm{Al}_{2} \mathrm{O}_{3}, 2 \mathrm{SiO}_{2}\right.$ : 3-2 mullite) to $x=0.40\left(2 \mathrm{Al}_{2} \mathrm{O}_{3}, \mathrm{SiO}_{2}: 2-1\right.$ mullite). Many works have been devoted to this material (elaboration by different methods, thermomechanical characterization, reinforcement with particles or whiskers) as it possesses remarkable properties: low expansion coefficient $\left(5 \times 10^{-6} \mathrm{~K}^{-1}\right.$ in the temperature range $\left.20^{\circ} \mathrm{C}-800^{\circ} \mathrm{C}\right)$, good thermal shock resistance, high creep resistance $\left(\mathrm{d} \varepsilon / \mathrm{dt}>10^{-10} \mathrm{~s}^{-1}\right.$ at $\left.1200^{\circ} \mathrm{C}\right)$ and flexural strength (above $360 \mathrm{MPa}$ ) [2-4]. Moreover, mullitebased materials show a high resistance towards most acid and basic chemical agents. But the presence of mullite in clay-based traditional ceramics does not always induce high thermomechanical (TM) performances [5,6]. This may be explained by the fact that, in these materials, mullite is then associated with a huge volume of vitreous phase (30\% to $70 \%$ ), others minerals (quartz...) and essentially an important porosity.

In natural conditions, andalusite $\left(\mathrm{Al}_{2} \mathrm{SiO}_{5}\right)$ is an aluminosilicate associated with metamorphic rocs. This ore is thermally instable and transforms into 3-2 mullite:

$$
\begin{aligned}
& 3\left(\mathrm{Al}_{2} \mathrm{SiO}_{5}\right) \rightarrow \underset{\text { Andalusite }}{\left(3 \mathrm{Al}_{2} \mathrm{O}_{3}, 2 \mathrm{SiO}_{2}\right)+\mathrm{SiO}_{2}} \text { Mullite Amorphous silica }
\end{aligned}
$$

\footnotetext{
"Corresponding author.
}

Thus, the high TM properties of mullite-based refractory bricks obtained from natural aluminosilicates like andalusite are ascribed to the presence of an important proportion of mullite (up to $80 \mathrm{wt} \%$ ), a silicarich vitreous phase and a low porosity [7].

In the following, we seek to value widely available Moroccan andalusite-rich schists, by enrichment of the natural ore. Investigations are focussed on mullite formation process and the correlation of the structural properties with the mechanical characteristics.

\section{Materials and Experimental Methods}

The starting material is schist from Marrakech area in the centre region of Morocco. The chemical composition, assessed by X-ray fluorescence analyses (FRX, Magi X Pro), shows the presence of silica $\mathrm{SiO}_{2}$ (53.57 wt\%), alumina $\mathrm{Al}_{2} \mathrm{O}_{3}$ (10.52 wt\%) and hematite $\mathrm{Fe}_{2} \mathrm{O}_{3}(7.23$ $\mathrm{wt} \%)$ as the major oxides. XRD analyses on powders (X'pert Pro data collector, PaNalytical Lci/712) reveal the presence of andalusite, muscovite, quartz and biotite as principal minerals [8].

The enrichment in andalusite of the starting powder was implemented through few concentration steps [9]: After crushing, the powder undergoes successive sieving steps until the obtainment of an extract referred as An-Cn. The An-Cn powder was crushed in a jar using alumina balls and the grain size distribution was assessed by using Cylass 920 laser beam analyser. Slurry prepared by 
mixing this powder with $30 \mathrm{wt} \%$ of water and $2 \mathrm{wt} \%$ of dispersant was dried in an oven for 24 hours at $120^{\circ} \mathrm{C}$ for compacts elaboration. These samples were then heated in a muffle furnace (Nabertherm) in the temperature range $1200^{\circ} \mathrm{C}-1600^{\circ} \mathrm{C}$ at a heating rate of $7^{\circ} \mathrm{C} / \mathrm{min}$ and a dwell of two hours. Thermal expansion was investigated by using a Setaram type apparatus. Porosity measurements were performed on a Poremaster 60 type (Quantacrom) device. Grains morphology was assessed by scanning electron microscopy observations (Carl Zeiss Supra 55 device) and qualitative investigations of the sintered materials were performed by electron dispersive spectroscopy analyses.

For the mechanical tests, rectangular bars with length $\mathrm{L}=20 \mathrm{~mm}$, width $\mathrm{l}=4 \mathrm{~mm}$ and thickness $\mathrm{W}=4 \mathrm{~mm}$ were cut from the sintered samples by using a diamond saw. Smooth specimens were loaded in three point bending for strength measurement and single edge notched beam (with relative notch length $\mathrm{a} / \mathrm{W}=0.35$ ) were used for fracture toughness evaluation. The tests were run on Instron load frame equipped with a $10 \mathrm{kN}$ capacity load cell. Hardness measurements were performed on a Zwick type indenter.

\section{Results and Discussion}

\subsection{An-Cn Powder and Sample Preparation}

The chemical composition of An-Cn shows that the main oxides are alumina and silica (Table 1). XRD analysis of the An-Cn powder (Figure 1) indicates the major phases: andalusite associated with quartz and muscovite. The grain size distribution shows a unimode distribution with a mean grain size of about $9.30 \mu \mathrm{m}$ (Figure 2). The compaction diagram of the An-Cn powder was determined (Figure 3) and used to elaborate disc-shaped samples (30 $\mathrm{mm}$ in diameter) by unidirectional pressing at 60 $\mathrm{MPa}$, the limit above which agglomerates crush and the closed porosity reduces [10].

\subsection{Phase Transformations}

The X-ray diagrams of An-Cn calcinated in the temperature range $1200^{\circ} \mathrm{C}-1600^{\circ} \mathrm{C}$ are shown in Figure 4 . Crystallisation of mullite begins as early as $1200^{\circ} \mathrm{C}$. Total transformation into mullite is likely obtained above $1450^{\circ} \mathrm{C}$. In process of calcination, andalusite transformation is accompanied by the formation of a silicarich liquid phase responsible for the densification of the compact. The densification occurs through vitreous phase formation process, the evolution of which as a function of temperature can be evaluated by the amount of open porosity (Figure 5). The open porosity decreases slowly in the temperature range $1200^{\circ} \mathrm{C}-1450^{\circ} \mathrm{C}$, and then strongly falls off to zero value at $1550^{\circ} \mathrm{C}$. That behaviour reminds former results reported about the Damrec trade andalusite product [11]. It appears that the mullite formation rate, related to the formation of the vitreous phase, strongly depends on temperature with a drastic increase above $1450^{\circ} \mathrm{C}$.

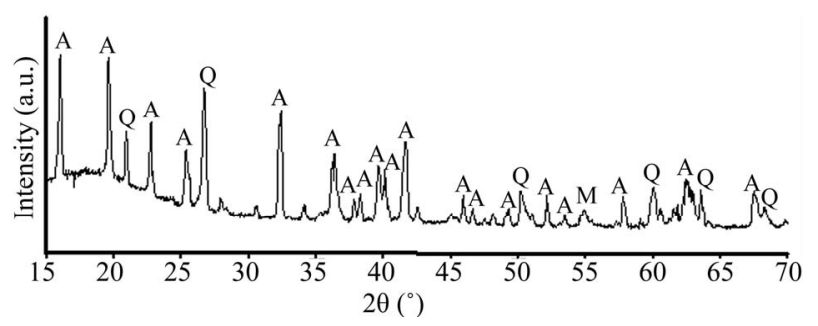

Figure 1. X-ray diffraction diagram of An-Cn powder (A: andalusite; $\mathrm{M}$ : muscovite and Q: quartz).

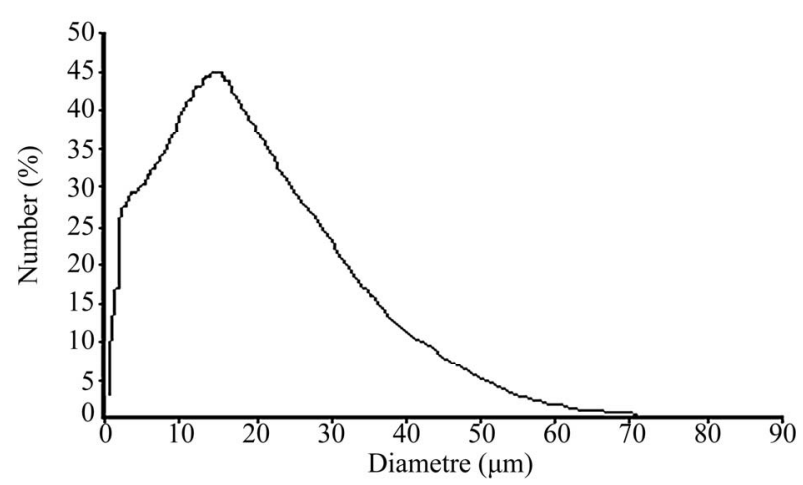

Figure 2. Grain size distribution of An-Cn powder.

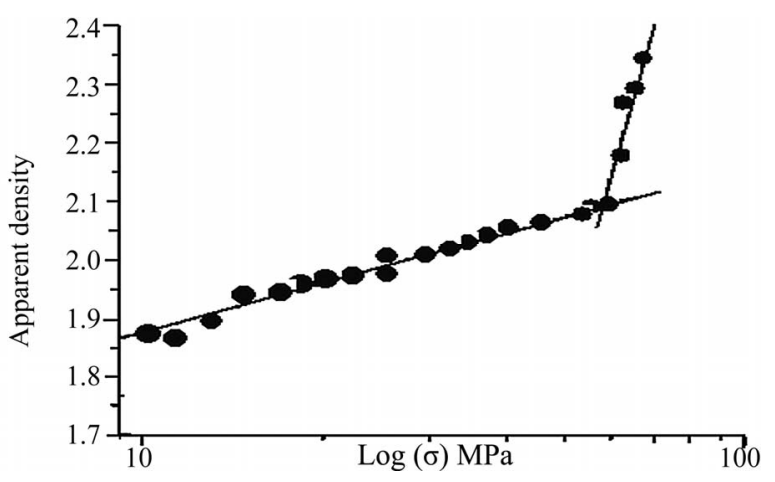

Figure 3. Compaction diagram of An-Cn powder.

Table 1. Quantitative chemical composition of An-Cn powder (wt\%).

\begin{tabular}{ccccccccccc}
\hline Oxide & $\mathrm{SiO}_{2}$ & $\mathrm{Al}_{2} \mathrm{O}_{3}$ & $\mathrm{Fe}_{2} \mathrm{O}_{3}$ & $\mathrm{TiO}_{2}$ & $\mathrm{CaO}$ & $\mathrm{MgO}$ & $\mathrm{Na}_{2} \mathrm{O}$ & $\mathrm{MnO}$ & $\mathrm{K}_{2} \mathrm{O}$ & Loss on Ignition \\
\hline An-Cn & 38.50 & 57.06 & 1.37 & 0.50 & 0.10 & 0.13 & 0.05 & 0.01 & 0.20 & 0.61 \\
\hline
\end{tabular}




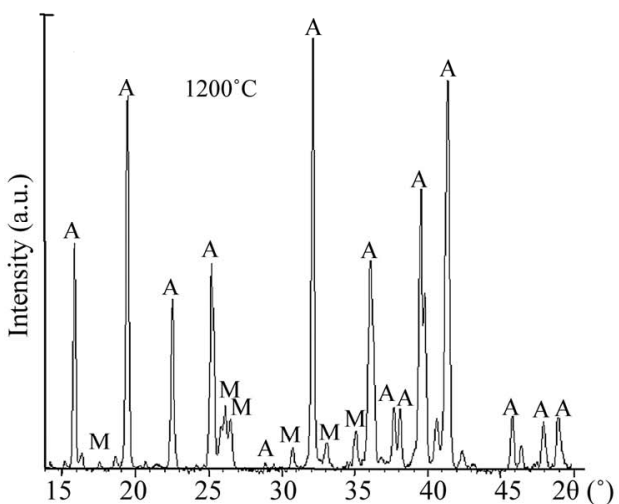

(a)

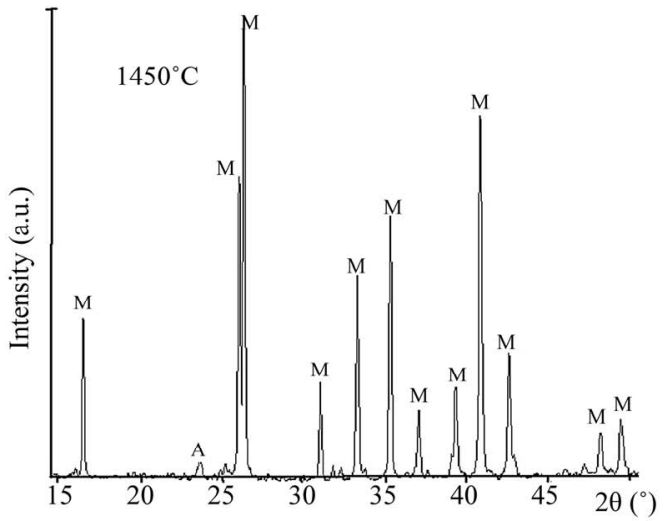

(c)

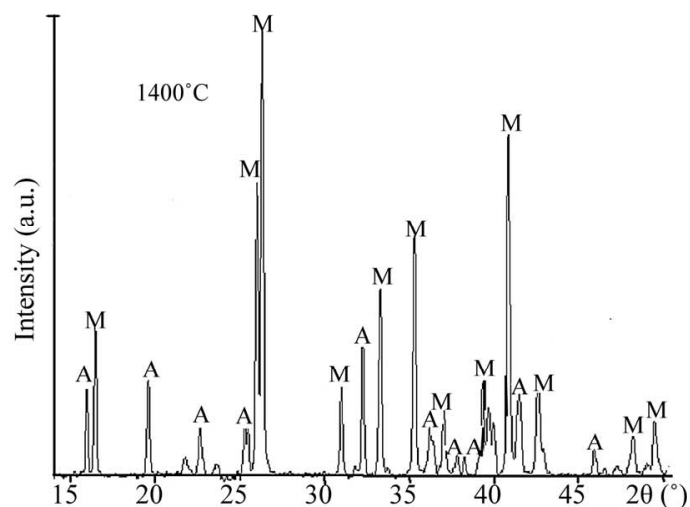

(b)

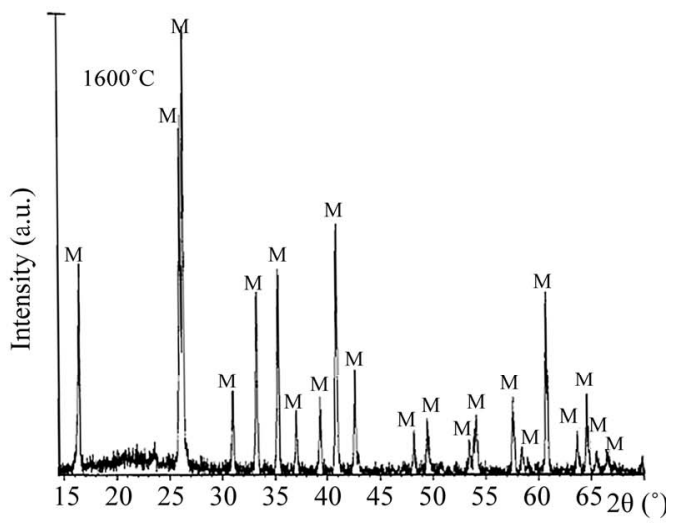

(d)

Figure 4. X-ray diffraction diagrams of An-Cn calcinated at $1200^{\circ} \mathrm{C}, 1400^{\circ} \mathrm{C}, 1450^{\circ} \mathrm{C}$ and $1600^{\circ} \mathrm{C}$.

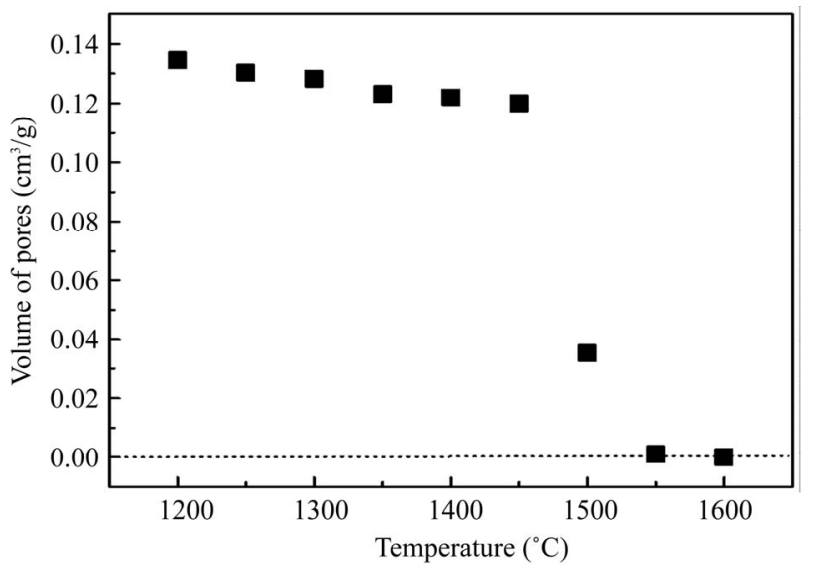

Figure 5. Evolution of the porosity with the annealing temperature.

For microstructure observation on the surfaces of rupture, the amorphous phase at the grain bondaries was removed by hydrofluoric acid attack. The fractured surface of a piece of sample fired at $1600^{\circ} \mathrm{C}$ reveals the presence of aggregates made of equiaxed mullite grains (Figure 6(a)). A similar morphology has been observed later on for a material processed starting from sillimanite [12]. An EDX analysis shows that the mullite solid solu- tion doesn’t contain foreign inclusions (Figure 6(b)).

\subsection{Thermal Behavior}

The thermal behaviour of An-Cn is shown in Figure 7. Shrinkage beginning at around $1000^{\circ} \mathrm{C}$ corresponds to the first stage of sintering. One notes a marked deceleration of the shrinkage rate at around $1200^{\circ} \mathrm{C}$, imputed to the onset of mullite crystallisation. The total shrinkage amplitude is low: about $3.5 \%$ at $1450^{\circ} \mathrm{C}$.

\subsection{Resistance towards Acid Attack}

The resistance towards sulfuric acid was checked according to NF EN 993 - 16 standards dealing with dense shaped refractory products [13]. First, the refractory material was ground to a mesh size comprised between 0.63 and $0.80 \mathrm{~mm}$, and then dried. A mass $\mathrm{m}_{\mathrm{i}}$ of this material was then treated in a boiling solution of concentrated sulfuric acid (18N). The slurry was rinsed, filtered, dried and the obtained powder was weighted (final mass $\mathrm{m}_{\mathrm{f}}$ ). The relative mass reduction after acid treatment is reported in Figure 8. The continuous decrease of the relative mass reduction as a function of the annealing temperature confirms higher resistance towards acid attack as the amount of formed mullite is increased. 


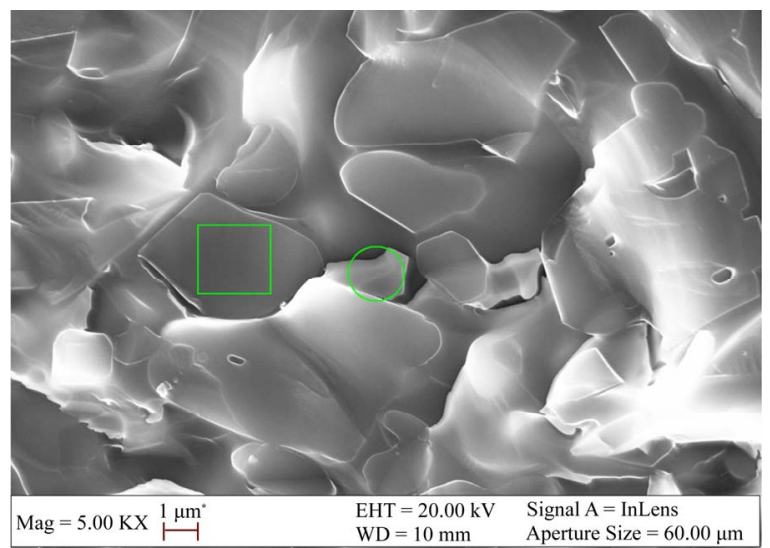

(a)

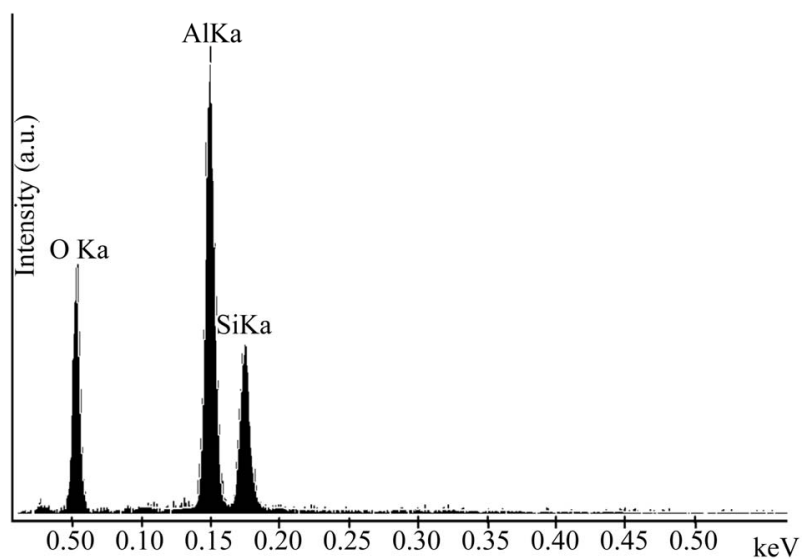

(b)

Figure 6. (a) SEM microphotography of a sample fired at $1600^{\circ} \mathrm{C}$; (b) EDX analysis of the square area in (a).

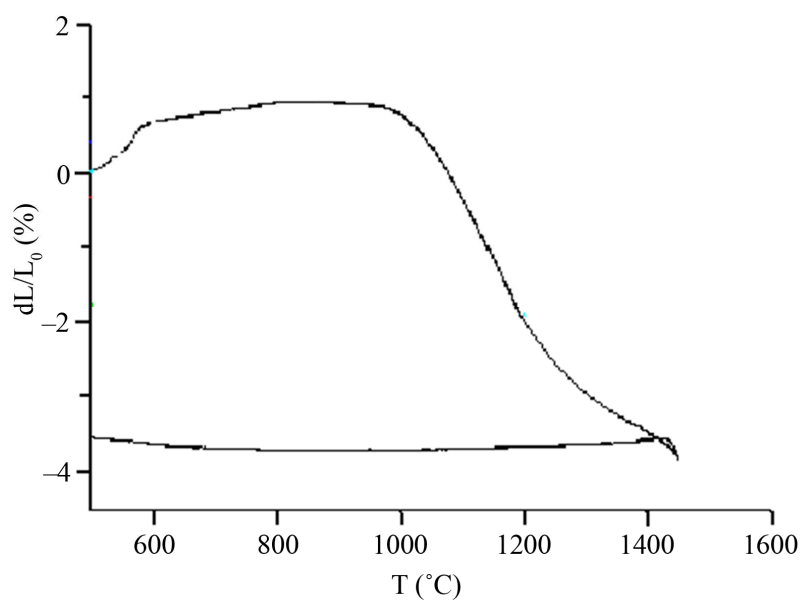

Figure 7. Thermal expansion behaviour of An-Cn powder.

\subsection{Mechanical Properties}

Flexural strength and fracture toughness values are reported in Table 2. These values are similar to the ones reported in the literature for equivalent materials [14]. In Figure 9 the strength is almost constant for sintering temperature below $1450^{\circ} \mathrm{C}$, and then rises steeply. That points out the drastic influence of the presence of structural defects, namely surface flaws. High strength values noted for sintering temperature above $1450^{\circ} \mathrm{C}$ are ascribed to mullite formation but also to the presence of the vitreous phase which fills in the open porosity. The toughness evolution shows a different trend: it increases quite linearly with the sintering temperature.

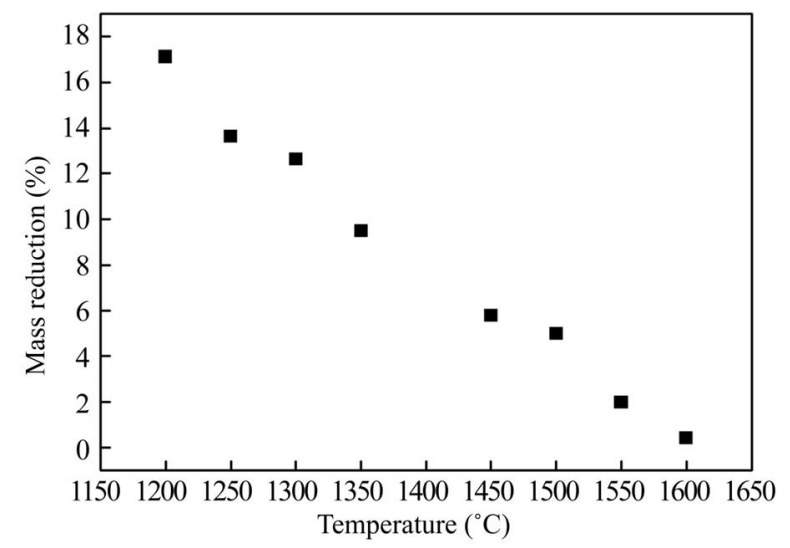

Figure 8. Evolution of the relative mass reduction with the annealing temperature.

Table 2. Mechanical properties of the different materials.

\begin{tabular}{cccc}
\hline $\begin{array}{c}\text { Temperature } \\
\left({ }^{\circ} \mathrm{C}\right)\end{array}$ & $\begin{array}{c}\text { Flexural } \\
\text { strength (MPa) }\end{array}$ & $\begin{array}{c}\text { Toughness } \\
\left(\text { MPam }^{1 / 2}\right)\end{array}$ & $\begin{array}{c}\text { Vickers } \\
\text { hardness Hv } \\
(\mathrm{GPa})\end{array}$ \\
\hline 1200 & 27.24 & 0.93 & 2.20 \\
1450 & 34.80 & 1.41 & 2.90 \\
1500 & 80.30 & 1.63 & 3.30 \\
1550 & 115 & 1.75 & 4.70 \\
1600 & 136 & 1.99 & 6.97 \\
\hline
\end{tabular}

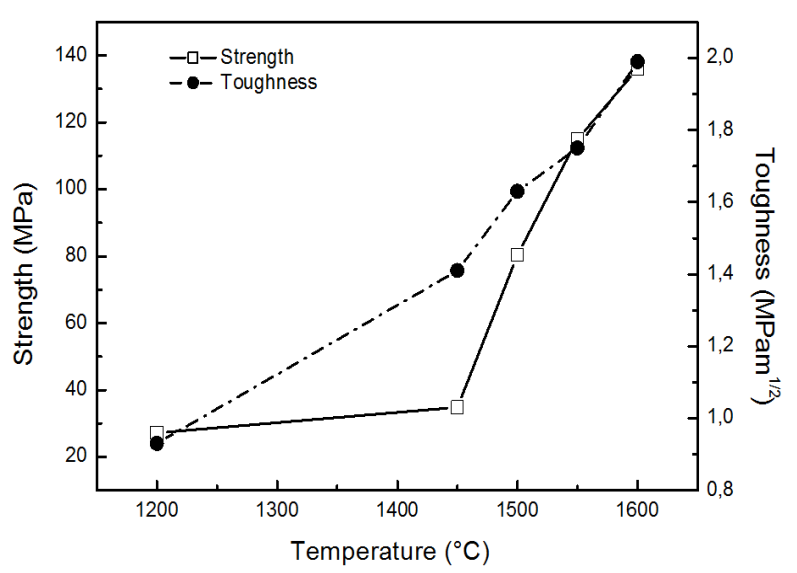

Figure 9. Evolution of the mechanical characteristics with the annealing temperature. 


\section{Conclusions}

Starting from schist mined in the Centre Region of Morocco, we have obtained an andalusite-rich material through an enrichment process. The analyses of phase transformations and the investigation of structural properties as a function of annealing temperature show that this material compares favourably with similar trade powders:

1) Total transformation into mullite and amorphous phase is obtained at temperatures as low as $1550^{\circ} \mathrm{C}$; an investigation on the andalusite-mullite transformation kinetic is under way;

2) Very good dimensional stability is obtained upon firing;

3) Good mechanical characteristics and chemical resistance are obtained.

\section{Acknowledgements}

The authors wish to thank the Centre d'Etude et de Recherche des Phosphates Minéraux (Cerphos, Morocco) for their collaboration and financial support.

\section{REFERENCES}

[1] W. E. Cameron, "Mullite: A Substituted Alumina,” American Mineralogist, Vol. 62, 1977, pp. 747-755.

[2] I. Peretz and R. C. Bradt, "Andalusite Derived MulliteMatrix Refractories,” Ceramic Transaction, Vol. 6, 1987, pp. 613-633.

[3] M. Mizuno, "Microstructure, Microchemistry and Flexural Strength of Mullite Ceramics," Journal of the American Ceramic Society, Vol. 74, No. 12, 1991, pp. 3017-3022. doi:10.1111/j.1151-2916.1991.tb04295.x

[4] I. A. Aksay, D. M. Dabbs and M. Sarikaya, "Mullite for Structural, Electronic, and Optical Applications,” Journal of the American Ceramic Society, Vol. 74, No. 10, 1991, pp. 2343-2358. doi:10.1111/j.1151-2916.1991.tb06768.x

[5] A. Yamuna, S. Devanarayanan and M. Lalithambika, "Phase-Pure Mullite from Kaolinite," Journal of the American Ceramic Society, Vol. 85, No. 6, 2002, pp. 1409-1413. doi:10.1111/j.1151-2916.2002.tb00289.x

[6] E. W. Lee, G. P. Souza, C. J. McCoville, T. Tarvorn- panich and Y. Iqbal, "Mullite Formation in Clays and Clay-Derived Vitreous Ceramics," Journal of the European Ceramic Society, Vol. 28, No. 2, 2008, pp. 465-471. doi:10.1016/j.jeurceramsoc.2007.03.009

[7] J. P. Ildefonse, V. Gabis and F. Cesbron, "Mullitization of Andalusite in Refractory Bricks," Key Engineering Materials, Vol. 132-136, 1997, pp. 1798-1801. doi:10.4028/www.scientific.net/KEM.132-136.1798

[8] A. Arib, R. El Ouatib, T. Remmal and R. Moussa, "Thermal Behaviour and Structural Transformations of Andalusite-Rich Aluminous Nodules from Morocco," Key Engineering Materials, Vol. 264-268, No. 3, 2004, pp. 1815-1818.

doi:10.4028/www.scientific.net/KEM.264-268.1815

[9] A. Arib, "Valorization of Local Raw Materials by Their Introduction in Industrial Formulations (Ceramic Tiles) and the Elaboration of Silico-Aluminous Ceramic Refractories,” Ph.D. Dissertation, Université Hassan II Aïn Chock, Casablanca, 2005.

[10] H. Zanzoun, E. Jabry, M. Gomina and R. Moussa, “Compaction Ability and Influence of the Compaction Pressure on Clay-Based Powders Sintering," Proceedings of the 4th European Ceramics Society Conference, Vol. 11, 1995, pp. 57-65.

[11] M. L. Bouchetou, J. P. Ildefonse, J. Poirier and P. Daniellou, "Mullite Grown from Fired Andalusite Grains: The Role of Impurities and of the High Temperature Liquid Phase on the Kinetics of Mullitization and Consequences on Thermal Shocks Resistance," Ceramics International, Vol. 31, No. 7, 2005, pp. 999-1005. doi:10.1016/j.ceramint.2004.10.015

[12] I. Ganesh and J. M. F. Ferreira, "Influence of Raw Material Type and of the Overall Chemical Composition on Phase Formation and Sintered Microstructure of Mullite Aggregates," Ceramics International, Vol. 35, No. 5, 2008, pp. 2007-2015. doi:10.1016/j.ceramint.2008.11.008

[13] BS EN 993-16, "Methods of Test for Dense Shaped Refractory Products. Determination of Resistance to Sulphuric Acide," 1995.

[14] F. Mazel, M. Gonon and G. Fantozzi, "Manufacture of Mullite Substrates from Andalusite for the Development of Thin Solar Cells," Journal of the European Ceramic Society, Vol. 22, No. 4, 2002, pp. 453-461. doi:10.1016/S0955-2219(01)00315-6 